\title{
The Jesuit Musical Tradition in the Polish-Lithuanian Commonwealth
}

\author{
Tomasz Je $\dot{z}$ \\ University of Warsaw \\ tomasz.jez@uw.edu.pl
}

\begin{abstract}
The article sums up the current state of research into the music of Jesuit communities in the Polish-Lithuanian Commonwealth in the years 1556-1773. In this region, the Society's engagement in cultivating various forms of musical culture was dictated primarily by considerations of pastoral and confessional natures in a country in which the Reformation remained a strong presence. Strategies of cultural activity were applied in the Polish and Lithuanian provinces with more freedom than in the remaining regions of the Society's German assistancy. These freedoms referred primarily to everyday forms of cultivating music in Jesuit-administered churches and schools, as ratified in the books of customs. A special role in the didactic and formative process was played by the school drama, rich in musical elements, as well as the so-called musical boarding schools. Although the surviving repertoire of Jesuit provenance is unrepresentative of the artistic tradition under scrutiny, we have reconstructed its character on the basis of intermediary sources.
\end{abstract}

\section{Keywords}

Jesuits - musical culture - Poland - Lithuania - boarding schools - school theater music repertoire

The appearance of the Jesuits in the Polish-Lithuanian Commonwealth marks a new epoch in the history of this country. Penetrated in various ways by contemporary Reformation thought, its vast expanses called for a decisive response from Roman Catholic circles. Members of the Society of Jesus active in Polish and Lithuanian lands joined in the discussion about the means for reviving

(C) JEŻ, 2018 | DOI:10.1163/22141332-00503003

This is an open access article distributed under the terms of the prevailing CC-BY-NC license at the time of publication. 
Roman Catholic orthodoxy. The formula they proposed quickly gained dominant status among the voices of local church circles and among the various stances toward the tolerant paradigm of a Commonwealth of many nations, cultural traditions, and confessions.

The Jesuit reform proposals were addressed primarily to the people within the Catholic community and were meant to revive their charisma on spiritual and intellectual levels. Above all, they postulated a thorough reform of the school system and a revision of pastoral methods, as well as a systematic introduction of new forms of spirituality. The means for achieving this were the establishment of a new type of educational institution, intensifying biblical, catechetical, preaching, and publishing efforts, and fostering school and state congregations for the laity. ${ }^{1}$ Naturally, successes in these fields and the elaborated strategies influenced other communities: for the dissenters in the region, they represented competition to their own religious cultures.

In all these forms of activity, the Jesuits readily used music, although it was not prescribed by their statutes. The first legislative formulas of the Society of Jesus deprecated any direct engagement on the part of professed Jesuits in any form of musical activity. ${ }^{2}$ However, both Paul IV's bull Dilectis filiis $(1539)^{3}$ and the Society's constitutions (1541) ${ }^{4}$ refer only to the monastic tradition of communal officium singing - which the newly created order wished to abandon. Neither document rejected, in the least, the possibility of cultivating selected forms of religious musical tradition, choosing only to subordinate their use to the priority of pastoral goals. ${ }^{5}$

However, exceptions to the norms were soon introduced, on the one hand to pacify the critical views of Pope Carafa (Paul IV), and on the other hand to allow a richer musical practice in the Roman Collegium Germanicum than

1 Stanisław Obirek, Jezuici w Rzeczypospolitej Obojga Narodów w latach 1564-1668: Działalność religijna, spoteczno-kulturalna i polityczna (Cracow: Wydawnictwo WAM, 1996).

2 Thomas D. Culley, Jesuits and Music: I. A Study of the Musicians Connected with the German College in Rome During the $17^{\text {th }}$ Century and Their Activities in Northern Europe (St. LouisRome: St. Louis University-Institutum Historicum Societatis Iesu, 1970); T. Frank Kennedy, "Jesuits and Music: The European Tradition, 1547-1622" (PhD diss., University of California, Santa Barbara, 1982).

3 Sancti Ignatii de Loyola Constitutiones Societatis Jesu, vol. 1: Monumenta Constitutionum praevia, ed Arturo Codina (Rome: Institutum Historicum Societatis Iesu, 1934), 19.

4 Constitutiones Societatis Iesu a Congregatione Generali XXXIV annotatae et Normae complementariae ab aedem Congregatione approbatae (Rome: Institutum Historicum Societatis Iesu, 1995), no. 586.

5 Constitutiones, no. 587 . 
was available elsewhere. ${ }^{6}$ The substantial argument for this dispensation was the need for the most comprehensive training possible, including in music, for the adepts of the institution coming from the north of Europe. They were educated, among other things, so as to be able to oppose Protestant culture in their native countries. In respect to the territories considered as missionary (both those under the influence of the Reformation and those still "pagan"), nurturing various forms of musical culture was permitted and of utility to the Jesuits sent on missionary work. The dispensation was officially approved by the Society's Third General Congregation in $1573 .{ }^{7}$

The dispensation was obviously also in force in Polish and Lithuanian territories, abounding in other confessions propagated mainly among the local noble and middle-class circles. As the equal rights of various religious professions in the Commonwealth had been confirmed by the Warsaw Confederation (1577), Jesuits were required to use conscientious strategies of action, even in their own circles, to nurture the artistic traditions. These strategies were similar in countries of "special need," where the necessity of introducing music created analogous problems, usually resolved in a similar way. ${ }^{8}$ While most of the Society's German centers did attempt to temper the expressed need for cultivating richer forms of musical culture these restrictions were always verified by local practice. ${ }^{9}$

The situation was similar in Jesuit residences and colleges in the Commonwealth. Fathers active in these centers confronted the elevated expectations of the local hierarchs as to the musical setting of the liturgy, not only in churches administered by the Jesuits but also in other places of worship in a given city. The fluid division of competencies resulted in a conflict between Stanisław Rozdrażewski, the rector of Pułtusk college, and Piotr Myszkowski, the bishop of Płock, as early as in the first year of the college's activities. The Austrian provincial Lorenzo Maggio attempted to resolve these controversies, ${ }^{10}$ but was

6 Vita Ignatii Loiolae et rerum Societatis Iesu Historia, auctore Joanne Alphonso de Polanco ejusdem Societatis sacerdote, ed. Iosephus M. Vélez (Madrid: Augustinus Avrial, 1898), 5:33.

7 Institutum Societatis Iesu, vol. II, Examen et Constitutiones: Decreta congregationum generalium; Formulae congregationum (Florence: ex Typographia a ss. Conceptione, 1893), 539 .

8 Archivum Romanum Societatis Iesu, Rome [hereafter ARSI], Instit. 185 I, ff. $14^{\mathrm{r}-\mathrm{v}}$.

9 Tomasz Jeż, Kultura muzyczna jezuitów na Ślasku i ziemi kłodzkiej (1581-1776) (Warsaw: Wydawnictwo Naukowe Sub Lupa, 2013), 118-40.

10 Kennedy, Jesuits, 69-70. 
unsuccessful, as evidenced by the Roman secretary of the Superior General expressing a position in the same matter a couple of years later. ${ }^{11}$

The musical life of the first Polish Jesuit college, founded in 1565 in Braniewo, did not necessitate such an intervention. In the instructions sent to this center, the provincial approved of most of its practices, including chant singing of Mass and vespers, as well as the polyphonic repertoire performed at the more important liturgical feasts (the music had to comply with the norms accepted by the Council of Trent) and vernacular songs at Corpus Christi processions. ${ }^{12}$ The latter repertoire was recommended also for the Vilnius (Wilno) college, founded in 1570, as local Jesuits were asked to support the laity in the singing of songs pro more patriae. ${ }^{13}$ However, at the congregation of the German assistancy of 1576, the conservatives gained the upper hand and advised the Polish Jesuits to practice music "rarely and with great restraint," while heeding the Jesuit charisma to which it was not particular. ${ }^{14}$

Zealous obedience to these instructions was shown by the Jesuits of the Poznan college, visited in 1580 by Maggio. In response to their doubts concerning musical practice, the visitor confirmed permission for the performance of a liturgically adequate Marian antiphon during feasts and vigils. Apart from several specific feasts, the musical setting was not planned and the situation was to remain as it had been before. ${ }^{15}$ The attention of the Society's authorities was drawn to the musical practice of St. Barbara's Church in Cracow, reported to Claudio Acquaviva by Giovanni Paolo Campana. While the Polish provincial did not object to the singing of the mansionaries active in this church and the musicians employed by the local Brotherhood of Mercy, as it drew the city dwellers to the Jesuits' sermons, he was astonished that they "reluctantly go there, where silence abounds,"16 and Piotr Skarga explained to the general: "this people cannot fathom the silence of our Society."17

11 Epistolae et commentaria P. Joannis Alphonsi de Polanco e Societate Jesu addenda caeteris ejusdem scriptis dispersis in his monumentis, quibus accedunt nonnulla coaeva aliorum auctorum illis coniunctissima, vol. 2, ed. Dionysius Fernández Zapico and Daniel Restrepo (Madrid: G. López del Horno, 1917), 152; Kennedy, Jesuits, 76.

12 ARSI, Instit. 209, ff. $189^{\mathrm{r}}-200^{\mathrm{r}}$.

13 Monumenta paedagogica Societatis Iesu, ed. Ladislaus Lukács (Rome: Institutum Historicum Societatis Iesu, 1965-92), 3:188; Jerzy Kochanowicz, Przepisy dotyczace jezuickich burs muzycznych (Cracow: Wydawnictwo WAM, 2002), 33.

14 ARSI, Congr. 42, f. 181' ; Monumenta paedagogica, 4:297-98.

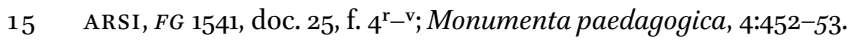

16 ARSI, Germ. 164, f. 187"; Kochanowicz, Przepisy, 49-50.

17 ARsi, Pol. 72 , f. $5^{\text {r }}$. 
Even earlier, the superior of the Cracow residence was called to answer for his willful allowance of music and his consent, without the provincial's approval, to the repair of the church's organ. ${ }^{18}$ According to Acquaviva's recommendations, the existing organs in Jesuit churches were to be tolerated but their gradual elimination and restraint towards the installation of new ones was to be sought. ${ }^{19}$ However, with time even this limitation ceased to be mandatory, among other things due to the pressure from the Polish Jesuits who insisted at the province's congregation in 1587 on a dispensation from the rules concerning music because the locals "cannot imagine a life without music and do not attend churches where eternal silence reigns." ${ }^{20}$ The general recommended avoiding all extremes in procedures and nurturing forms of musical practice that would not have the Jesuits stray from their statutory responsibilities or disrupt their fulfillment. ${ }^{21}$

Additional concessions from the authorities were sought by the 1607 Jarosław congregation of the Polish province, which sent arguments to the general for the widening of musical practice in a country where "nothing can be done in church without music."22 Polish Jesuits listed the inconveniences of the restrictive instructions in this domain. They also pointed out the positive aspects of possible changes in jurisdiction to make their mission more fruitful. Even before these Rationes pro musica were sent to Acquaviva, the general had consented to the presence of organs and wind instruments in the liturgy in the Polish province. ${ }^{23}$ After its division into the Polish and the Lithuanian provinces, the latter insisted on dispensations regarding music, justifying their necessity with the need to confront the competing traditions of other confessions, whose "heretics lure the simple people with song to their synagogues."24 The dispensations approved for the college at Vilnius concerning polyphonic

18 ARsi, Germ. 164, f. 100 ${ }^{\text {r }}$ Kochanowicz, Przepisy, 49.

19 ARSI, Pol. 3, f. 6r; Jerzy Kochanowicz, Geneza, organizacja i dziatalność jezuickich burs muzycznych (Cracow: Wydawnictwo WAM, 2002), 24.

20 ARSI, Congr. 43, f. $96^{\mathrm{r}-\mathrm{v}}, 101^{\mathrm{r}-\mathrm{v}}$.

21 ARsi, Pol. 3, f. $8^{\mathrm{v}}$.

22 ARSI, Congr. 52, f. 316 ${ }^{\text {r }}$; Kochanowicz, Przepisy, 60.

23 ARSI, Pol. 3, f. 13 ${ }^{\text {r }}$; Anna Szweykowska, "Wkład jezuitów w kulturę muzyczną Rzeczypospolitej w XVII wieku," in Jezuici a kultura polska: Materiaty sympozjum z okazji jubileuszu 5oo-lecia urodzin Ignacego Loyoli (1491-1991) i 45o-lecia powstania Towarzystwa Jezusowego (1540-1990), ed. Ludwik Grzebień and Stanisław Obirek (Cracow: Wydawnictwo WAM - Księża Jezuici, 1993), 297-308.

24 ARSI, Congr. 53, f. 248, $252^{\mathrm{v}}$; Szweykowska, Wktad, 298. 
music, though still restricted to the feasts, Sundays, and the carnival period, are a testimony to the success of these attempts. ${ }^{25}$

From the beginning of the seventeenth century, the musical practices of particular provinces and centers were regulated by the books of customs. Consuetudines described those norms of Jesuit institutional functioning that fell neither under the canon law, nor within the Jesuit Constitutions, but presented a system of rules cultivated and effective in a given place. Sources of this type document the musical practice of specific churches, schools, or sodalities. ${ }^{26}$ We are able to describe more precisely the musical culture of the Polish and Lithuanian provinces on the basis of surviving books of customs belonging to the region, especially since their level of detail extends significantly beyond the norms accepted in similar documents prepared for the other provinces of the German assistancy.

The consuetudines templi ${ }^{27}$ set down for the Polish province allowed the singing of the Mass and vespers at the major feasts of the liturgical year, Advent Sundays, and commemorations of Jesuit saints. Sermons preached in the churches were preceded by a liturgically appropriate song, while Corpus Christi vespers were accompanied by the singing of the Litany of the Most Blessed Sacrament. The funeral liturgy is also described in detail: the officium was chanted clara sed sine cantu voce, the procession with the coffin advanced in turn with the psalm Miserere and the ringing of bells. A very different practice accompanied the carnival days when the liturgy had a rich vocal-instrumental setting. The object of this maxime adhibenda musica was to attract as many listeners as possible to the sermons.

The consuetudines scholasticae ${ }^{28}$ prepared for the Polish and Lithuanian provinces were still more detailed. They regulated not only the participation of the students of Jesuit gymnasiums in the sung Mass and vespers, but also enumerated the titles of particular songs performed during classes and church services in a given liturgical period. Thus, classes at the gymnasium opened with the singing of the hymn Iam lucis orto sidere, replaced at Christmastime with a carol and at Easter with the antiphon Surrexit Dominus. At noontime throughout the year, the hymn Veni Sancte Spiritus or Surrexit Christus hodie was sung. To close the classes, the students performed the hymn Te lucis ante terminum, replaced with the sequence Grates nunc omnes or the antiphon Regina coeli

25 Szweykowska, Wktad, 298.

26 Kateřina Bobková-Valentová, Každodenní život učitele a žáka jezuitského gymnázia (Prague: Karolinum, 2006), 21-51.

27 ARSI, Germ. 128, ff. $25^{\mathrm{v}}-302^{\mathrm{v}}$.

28 ARSI, Germ. 128, ff. $233^{\mathrm{r}}-234^{\mathrm{v}} ; 303^{\mathrm{r}}-312^{\mathrm{v}}$; Kochanowicz, Przepisy, 66-68. 
laetare. On Saturday afternoons and the vigils of Blessed Virgin Mary feasts, the attendees sung the Litany of Loreto, also repeated at the following Matins. Finally, on the Sundays of Great Lent, the latter was replaced by selections from the Passion in chant form, with the addition of the psalm Miserere on Fridays.

Holy Masses celebrated during the year with the participation of the gymnasium students included the singing of the following songs on the consecutive days of the week: Eripe me or Exaudi Deus (Monday), Jesu dulcis memoria (Tuesday), Sanctissima Maria or Maria Mater gratiae (Wednesday), Fiant Domine or Contere Domine (Thursday), Stabat Mater dolorosa (Friday), Ave Maris Stella or Maria Mater gratie (Saturday), as well as Domine Rex, Sub tuum praesidium, and Sancte Sebastiane. This order changed during Advent, ${ }^{29}$ Christmas, ${ }^{30}$ Great Lent, ${ }^{31}$ and Easter. ${ }^{32}$ Interestingly enough, the list was not supposed to be expanded further. During the octave of Corpus Christi the singing of songs sub sacro was entrusted to professional musicians who performed a repertoire appropriate to the occasion. ${ }^{33}$ However, the musical setting was assisted by the singing of students and instrumentalists from the Jesuit musical boarding schools; here, special care was taken when necessitated by considerations of the doctrinal rivalry with the Protestant majority in cities in Royal Prussia, such as Braniewo, Elbląg, Gdańsk, and Torun. ${ }^{34}$

The need for the musical training was definitely perceived in the Jesuit schools; $; 5$ the problem was, however, who would undertake it. The situation stemmed from the instructions of authorities of the Society stating that professed Jesuits could not teach music. ${ }^{36}$ On the other hand, the prefects of Jesuit schools were required to ensure the student's adequate musical schooling and

29 Po upadku cztowieka grzesznego; Gwiazdo morska; Urzad zbawienia wiecznego; Mittit ad Virginem; Ecce Dominus veniet; Archaniot Boży Gabryel.

30 When the singing of the following songs was planned: Resonet in laudibus; Puer natus in Bethlehem; Puer nobis nascitur; Nobis est natus hodie; In Natali Domini; Salve parvulae; Salve Jesu parvule; Dies est laetitiae; Coelum gaude; Promit vox; Venit lux; Angelus pastoribus; Angelus ad Pastores; Collaudemus Christum; Psallite senes; Psallite unigenito; Fit Porta Christi; Quem pastores laudavere; Pueri nativitas; Grates nunc omnes, and Largum vesper. Vexilla Regis; Crux fidelis; In Passione Domini; Rozmyślajmy dziś; Krzyżu święty; Płacze dzisiaj.

32 Surrexit Dominus; Surrexit Christus hodie; Victimae paschali laudes; Wesoty nam dzien nastat; Regina coeli; Christus iam surrexit.

33 Adorate, nunc totus orbis et alia muteta de corpore Christi.

34 Kochanowicz, Geneza, 28.

35 Stanisław Bednarski, Upadek i odrodzenie szkót jezuickich w Polsce: Studium z dziejów kultury i szkolnictwa polskiego (Cracow: Przegląd Powszechny, 1933), 497.

$3^{6} \quad$ Monumenta paedagogica, 3:87. 
the quality of singing. ${ }^{37}$ Effectively, they did not conduct musical instruction, limiting themselves to overseeing the gymnasium lessons given by externs. Maggio's instructions given to the colleges in Pułtusk ${ }^{38}$ and Braniewo ${ }^{39}$ confirm this practice. In any case, music in the gymnasium teaching program often filled a recreational function; such was also the case in the seminaries for the clergy founded by the Society's most important colleges, such as in Braniewo. ${ }^{40}$ The singing of songs at services was not the only duty of the seminary students; another was a thorough knowledge of chant—naturally, in the version revised after the Council of Trent, known as the Editio Medicaea (1614-15).

Seminaries established in Northern Europe mirrored the solutions to the educational problems of the Collegium Romanum, setting new standards for clerical training. ${ }^{41}$ These standards also referred to a widely conceived musical culture, channeled into the models of religious life promoted at the time and correlated with corresponding activities surrounding the liturgy. The Jesuits' approval of the newly created language of music was a key factor in the process of the European dissemination of new stylistic trends originating in Italy. This took place in many of the Commonwealth's musical centers, often visited by Italian musicians, many of whom came from Roman educational institutions administered by the Society. ${ }^{42}$

However, while the Jesuits active in Poland and Lithuania lent an ear to novelties in the domain of modern artistic music, they tended to neglect their own training in Gregorian chant, which experienced an unprecedented crisis at this time. Textbooks published by Zygmunt Lauksmin $(1597-1670),{ }^{43}$ a professor at the colleges in Braniewo and Vilnius, testify to attempts at overcoming the crisis. He published Ars et praxis musicae in usum studiosae iuventutis in collegiis SocietatisJesu (1667), later supplied with a newly edited Antiphonale and Graduale, which came out after the Council of Trent. The aim of these publications

\footnotetext{
$37 \quad$ Ibid., 2:62.

38 Ibid., 3:165.

39 Ibid., 3:204.

$40 \quad$ Ibid., 3:176; Ludwik Piechnik, Seminaria diecezjalne prowadzone przez jezuitów od XVI do XVIII wieku (Cracow: Wydawnictwo WAM, 2001), 65 .

41 Monumenta paedagogica, 2:394.

42 We may list for example the musicians of the royal ensemble of the House of Vasa in Warsaw who came from this very circle: Annibale Stabile, Asprilio Pacelli, Giovanni Francesco Anerio, and Kaspar Förster junior. Barbara Przybyszewska-Jarmińska, Historia muzyki polskiej, vol. III: Barok - część pierwsza 1595-1696 (Warsaw: Sutkowski Edition, 2006), 58-62.

43 Jūratė Trilupaitienè, "Zygmunt Lauksmin w życiu muzycznym Akademii Wileńskiej," Muzyka 36, no. 1 (1991): 101-15; Agnieszka Krzepkowska, Zygmunt Lauxmin: Traktat Ars et praxis musica (Warsaw: Wydawnictwo Naukowe Semper, 2012).
} 
was the restitution of traditional chant singing and the proper liturgical status to its repertoire. Drawing on his training in rhetoric (which he studied under Maciej Kazimierz Sarbiewski), Lauksmin developed an original method of chant instruction, founded on the principles of grammar and phonetics.

Lauksmin's suggestions may be considered a practical application of the interdisciplinary synthesis of sciences made by Athanasius Kircher in his Musurgia universalis (1650), read and imitated by Polish Jesuits. The German polymath's reception is documented in the writings of Wojciech Tylkowski $\left(1625^{-95}\right),{ }^{44}$ professor of theology, philosophy, and mathematics in Braniewo, Warsaw, and Vilnius. His Philosophia curiosa (Oliwa: Georg Franz Fritsch, 1680) concerns, among other things, the issues in acoustics considered at Jesuit schools, as well as the aesthetic questions useful in the didactic practice of the Society, which tied musical practice to the art of rhetoric and the psychological science of temperaments. The potential of the art of sounds ad affectus concitandos ${ }^{45}$ was confirmed by successive generations of Jesuits who readily used the performing arts in their didactic practice.

They successfully cultivated various forms of school drama in the gymnasiums of the Commonwealth ${ }^{46}$ where they enjoyed rather extensive creative freedoms. The latter related not only to the number of performances staged during the year but also to their genres and the use of vernacular languages, permitted considerably more often. ${ }^{47}$ Music formed an immanent element of the spectacles presented: it accompanied dramas performed at inaugurations of each school year, religious performances correlated with the liturgical calendar (Christmas, Easter, Corpus Christi), and occasional festivities organized for public and political events (e.g. royal visits, the signing of peace treaties).

The pragmatic character of these performances prompted departures from the norms of Aristotelian poetics. In view of its didactic function, they combined the actors' performance, declamation, emblematic art, pantomime, music, song, dance, and stage play into a unified whole. The synesthetic

44 Michał Bristiger, "Problemy muzyczne w traktatach Wojciecha Tylkowskiego," in Studia musicologica: Aesthetica, theoretica, historica: Księga pamiątkowa Zofii Lissy, ed. Elżbieta Dziębowska et al. (Cracow: Państwowe Wydawnictwo Muzyczne, 1979), 69-76.

45 Athanasius Kircher, Musurgia universalis, sive ars magna consoni et dissoni [...] (Rome: Francis Corbellet's heirs, 1650), A 578.

46 Jan Poplatek, Studia z dziejów jezuickiego teatru szkolnego w Polsce (Wrocław: Ossolineum, 1957); Dramat staropolski od początków do powstania sceny narodowej. Bibliografia, vol. II: Programy wydane drukiem do r. 1765, vol. I: Programy teatru jezuickiego, ed. Władysław Korotaj, Jadwiga Szwedowska, and Magdalena Szymańska (Wrocław: Ossolineum, Wydawnictwo Polskiej Akademii Nauk, 1976).

47 ARSI, Germ. 128, ff. 311 ${ }^{\mathrm{v}}-312^{\mathrm{r}}$; Obirek, Jezuici, 90. 
combination of these elements into a rhetorically coherent whole was conducive to rhetorical persuasion. ${ }^{48}$ Through its many aspects, the dramatic play's message also served the moral formation of its audiences and the interiorization of religious experience. ${ }^{49}$ In this domain, it may be considered as the artistic analogue of the Ignatian Spiritual Exercises, which used the applicatio sensuum method, i.e. the meditative engaging of experiences captured with the help of the imagination's senses. In any case, the fact that both phenomena, which referred to the world of imagination as well as events represented on the theatrical stage, were called repraesentatio was not incidental.

The conception of Jesuit drama described above explains the presence of music on a richly documented scale in the sources of colleges of the Commonwealth. Despite the loss of the corresponding musical notation, we are able to reconstruct its character and general poetics on the basis of intermediary sources. These are primarily the surviving theatrical programs $\left(563\right.$ items $\left.^{50}\right)$ from seventy-six Jesuit colleges, above all those of Vilnius, Warsaw, Braniewo, and Poznan. ${ }^{51} \mathrm{~A}$ comparative analysis of their content reveals common traits in the spectacles' structure, encompassing various types of formal-musical elements. Such elements were the opening sung prologues; songs and arias appearing in the action, underscoring its cumulated emotions; choruses crowning the acts, commenting on the content's moral aspect; and musical intermedi dividing the acts, integrating the play's content through music. The drama's musical elements also included scenically interwoven dance and ballet inserts, as well as pantomimes accompanying the scenae mutae; both these genres served not only to show off the actors and provide recreation for the spectators, but also to render the associated content more intense and autonomous.

Jesuit drama also contained scenes of strictly musical character, either in content or of typically musical connotations of topoi. ${ }^{52}$ In stage directions, there sporadically appear titles of works included in the performance; usually, however, without any indication of their authors. Melodies of chant

48 Barbara Bauer, "Multimediales Theater. Ansätze zu einer Poetik der Synästhesie bei den Jesuiten," in Renaissance-Poetik, ed. Heinrich F. Plett (Berlin-New York: Taylor \& Francis, 1994), 197-238, here 222.

49 Jan Okoń, Dramat i teatr szkolny: Sceny jezuickie XVII wieku (Wrocław: Ossolineum, 1970), 114.

50 The overall number of presentations is estimated at around 3000: Okoń, Dramat, 42.

$5^{1} \quad$ Anna Mieczkowska, Muzyka w szkolnym teatrze jezuickim na terenie Rzeczypospolitej w XVII i XVIII wieku (M.A. Diss., Uniwersytet Warszawski, 2006); Anna ReglińskaJemioł, Formy taneczne w polskim teatrze jezuickim XvirI wieku (Poznań: Wydawnictwo Poznańskie, 2012).

$5^{2}$ E.g. Drama de Arca (Pułtusk, 1623), Cracow, Biblioteka Jagiellońska, call no. $65^{89}$. 
provenance (Gloria in excelsis Deo), settings of psalm texts (Ecce quam bonum), stylized carols (Dziwne rzeczy widziatem), and popular repertoires were also used. The spectacles included a recitative borrowed from contemporary operas: Heraclius Persarum dominator (1665), staged in Braniewo, was furnished with musica exhibita cum gestu et actione. ${ }^{33}$ The composer of the music for this drama play could have been Martin Kretzmer who was staying in the college at this time. Achab (1566), staged almost a century earlier in Pultusk, was in turn supplied with music by "Victoria of Spain," probably Tomás Luis de Victoria. ${ }^{54}$ The Spanish or Italian genesis of the music performed in Polish Jesuit drama plays could be confirmed by the repertoire spread in many sources of this time and the huge number of musicians migrating to Poland from Southern Europe.

In the spectacles presented by the Jesuit gymnasiums there appear frequent mentions of the musical instruments used. The latter were played not only in the intermedi dividing the various scenes but also within the scenes themselves, when it was warranted by the action or aesthetic considerations. Instruments accompanied the characters and constituted a kind of musical characterization of the content or affect expressed. In the Eucharistic spectacle presented in Vilnius in 1614, the violin and regal accompanied the parts sung by "Faith," while the lute and zither served the portions of text given to the "Crown of Victory." Moreover, key scenes in the spectacle's action were illustrated by the music of selected instrumental ensembles: the portrayal of Abraham's victory was accompanied by Pan's flute, the surma, and drums, while the image of Christ laid in his tomb was served by the harp, cornets, and the pommer. ${ }^{55}$ These instruments were usually played by members of the musical boarding schools - a special type of educational institution run by the Society.

The boarding schools staffed by the Jesuits ${ }^{56}$ were a type of school with a specifically musical profile. Since they were first designed for lay youth from the

\footnotetext{
53 Szweykowska, Wktad, 305-6.

54 According to Kochanowicz, Geneza, 36, this is the Spanish Jesuit Juan de Victoria.

55 Okoń, Dramat, 105-6.

$5^{6}$ Olga Dadiomowa, "Materiały do historii burs muzycznych na terenie współczesnej Białorusi w XVIII i na początku XIX w.," Muzyka 35, no. 2 (1990), 83-94; Ludwik Grzebień, "Bursy muzyczne," in W stużbie cztowiekowi. Studium duszpastersko-katechetyczne (Cracow: Wydział Filozoficzny Towarzystwa Jezusowego, 1991), 184-89; Roman Pelczar, "Jezuickie bursy muzyków (bursae musicorum) w diecezji przemyskiej w XVII i XVIII w.," Muzyka 43, no. 1 (1998): 73-87; Jolanta Woźniak, "Jezuickie bursy muzyczne w Polsce," in Dzieto muzyczne między inspiracją a refleksją: Księga Pamiątkowa na 6o-lecie urodzin Marka Podhajskiego, ed. Janusz Krassowski (Gdańsk: Akademia Muzyczna im. Stanisława Moniuszki, 1998), 73-88; Ludwik Grzebień and Jerzy Kochanowicz, "Jezuickie bursy muzyczne w dawnej Polsce: Zarys problematyki badawczej," Muzyka 47, no. 1 (2002):
} 
families of modest means, these establishments were called "the poor boarding schools" (bursae pauperum). However, as the social profile of the schools' adepts gradually changed, from the 1620 s these institutions were termed "musical boarding schools" (bursae musicorum). They were the local equivalent of the Jesuit-founded schools for externs, usually led as regular boarding schools and called - depending upon the type of founding and destination - convicti or seminaries. ${ }^{57}$ These institutions were usually created at Jesuit colleges according to the well-tried Roman model of Collegium Germanicum - an establishment with a definite, musical profile of training. ${ }^{58}$ This Roman school soon became a key centre of Baroque music for the entire Europe; the convicti established throughout the continent were important centers of dissemination for this new style, raising the level of musical education in leaps and bounds.

In the spirit of the Jesuit Constitutions, ${ }^{59}$ the convicti primarily accepted boys from families of modest means whose disposition was educationally promising. However, these schools were sometimes also open to children of the middle class, the nobility, and even aristocracy, able to cover the costs of room and board themselves. Care over the establishment was extended by the rector of the local college, but the actual directorship belonged to the convictus regent, assisted by the vice-regent, minister, and prefects responsible for the students' education. ${ }^{60}$ The youths' mode of life was regulated by the rhythm of communal prayers, classes, music lessons, and liturgical performances. ${ }^{61}$ All these elements served the students' character formation conducted with the goal of psychic and moral maturity, as well as professional training. Among the ideals of the boarders' forms of activity - morum probitas, studium litterarium

65-84; Jerzy Kochanowicz, "Jesuit Music Seminaries in Poland and Lithuania During the $17^{\text {th }}$ and $18^{\text {th }}$ Centuries," Studia Comeniana et historica 36 (2006): 172-77; Jerzy Kochanowicz, Stownik geograficzny jezuickich burs muzycznych (materiaty) (Cracow: Wydawnictwo WAM, 2002).

57 Andreas Steinhuber, Geschichte des Kollegium Germanicum-Hungarikum in Rom (Freiburg im Breisgau: Herder, 1906); Thomas D. Culley, "The Influence of the German College in Rome on Music in German-Speaking Countries During the Sixteenth and Seventeenth Centuries," Analecta musicologica 7 (1969): 1-36; 9 (1970): 20-94.

58 Joseph Schröteler, Die Erziehung in den Jesuiteninternaten des 16. Jahrhunderts (Freiburg im Breisgau: Herder \& Co. Verlagsbuchhandlung, 1940); Raffaele Casimiri, "Disciplina musicae' e 'Maestri di cappella' dopo il Concilio di Trento nei maggiori istituti ecclesiastici di Roma," Note d'archivio per la storia musicale 12 (1935): 1-26, 73-81; 15 (1938): 10-14, 49-64, 97-112, 145-56, 225-47; 16 (1939): 1-9; 19 (1942): 102-29, 159-68; 20 (1943): 1-17.

59 Constitutiones, no. 338.

6o Monumenta paedagogica, 3:123-26.

61 Ibid., 2:306. 
and peritia musices - the latter most clearly defined the mode of their social presence in culture. The latter one was very important, especially for the boys from the poor families: the access to free education was crucial for their life careers. For many boarders the musical practice opened the way for the further education and was the first step for their professional development.

Such was the case in all provinces of the Society of Jesus of the German assistance, i.e. also in the Commonwealth territory where musical boarding schools of the Jesuits played an especially important role. Apart from the boarding schools, schools connected to the dormitory and destined for the noble youth enjoyed popularity and are called here - in the narrow meaning of the term - convicti. ${ }^{62}$ The convicti for the nobility offered high level of education; some were transformed into academic colleges. Establishments of this type were founded in the mid-eighteenth century in Lviv (Lwów), Vilnius, Ostroh (Ostróg), Warsaw, Lublin, and Poznań. However, the music and dance education conducted there constituted extracurricular classes and did not bring as rich results within the sphere of musical culture as those mustered by the long-standing musical boarding schools.

The first musical boarding schools were created at colleges in Pułtusk (1568), Vilnius (1579), Braniewo (1582), Jarosław (1584), Riga (1584), Dorpat (now Tartu, 1592), and Kalisz (1590). From seventy-seven documented institutions of this type, nearly fifty were established in the seventeenth century; most continued to exist until the order's suppression; these which fell under the Russian partition, even longer. ${ }^{63}$ The boarding schools in Poland were primarily meant to serve the youths from the families of modest means in song and music training. Such an establishment required the creation of a foundation specifically designed for this purpose which was financially, administratively, and in terms of location dissociated from the college and gymnasium. The boarding schools' functioning was assured by interest accrued from entrusted land ownership, real estate, service-providing institutions and private foundations, gratuities and alms collected throughout the year, as well as remuneration for their artistic activity in the city's churches, schools, and sodality celebrations. The enumerated means were destined for supporting the establishment, remunerating contracted teachers and the service, paying the board as well as purchasing the clothing, instruments, and sheet music for the boarders.

The financial situation of the boarding school determined its size and number of trained students. Paweł Kostka's foundation, which began the boarding school in Pułtusk, was sufficient to provide for twelve students; the Cracow

\footnotetext{
62 Bednarski, Upadek i odrodzenie szkót jezuickich w Polsce, 439-64.

63 Kochanowicz, Geneza, 283-86.
} 
boarding school founded almost a century later (1645) trained around sixty musicians. ${ }^{64}$ The social profile of the students was also varied (although most came from the middle class, and less frequently from the milieu of nobility, clerics, and peasants), as was their national origin, especially in the larger urban centers. Regardless of the establishment size, they were similar in their educational goals and manner of organization. The period of study in the boarding schools last five to six years on average. During the first three years, the young adepts of music (inscripti) studied under the direction of professional contract musicians (salariati), while in the following two to three years they underwent a mandatory apprenticeship (as respectivi) in the same establishment as teacher assistants helping to train younger colleagues. ${ }^{65}$ The boys accepted by the boarding schools confirmed their will to respect these rules by signing standard contracts.

Normally, a priest known as the regent managed the school's property and conducted its bookkeeping and drawing up of reports. He was required to have administrative rather than musical qualifications, the latter being entrusted to his deputy_socius regentis, a function rarely noted in the catalogues prepared yearly in the respective centers. Information about the Jesuits' musical qualifications appearing in these documents is set down regularly from the midseventeenth century. From the reconstructed biographies of patres engaged in music it follows that in common practice they took over the responsibilities of boarding school regent deputy for two to three years during their teacher apprenticeship in the gymnasiums, usually before ordination. ${ }^{66}$ This is how the violation of the Society's prohibition for professed Jesuits to be actively occupied with music was avoided.

Musical training was considered to be a method for shaping the boarders' character, confirmed by the instructions to the first such school in Pułtusk, written by Maggio. ${ }^{67}$ Apart from following the detailed class schedule, the boarders were obliged to observe customary norms, in which the prefects were supported by assistants recruited from the student body. The etiquette also regulated ways of practicing the instruments and musical performance, both during liturgy and recreation. ${ }^{68}$ Boarding school regents were recommended

\footnotetext{
64 Ibid., 44, 75, 96.

65 Ibid., 95.

66 Stownik jezuitów muzyków i prefektów burs muzycznych, ed. Ludwik Grzebień and Jerzy Kochanowicz (Cracow: Wydawnictwo WAM, 2002).

67 Monumenta paedagogica, 3:168-69.

68 Ibid., 3:196-97, 200.
} 
to entrust their students with morality building repertoire. ${ }^{69}$ The musicians of Jesuit boarding schools played not only during the liturgy, pilgrimages, processions, and services, but also at sodality feasts, as well as school and theatre occasions of the gymnasium. They were also hired for the musical setting of church ceremonies (ingresses, funerals) and lay celebrations (wedding banquets, visits of distinguished guests), although this was often forbidden by their superiors, due to the rise of conflicts with the professional musicians, whom the boarders deprived of their special privileges.

Ensembles functioning in many towns alongside Jesuit boarding schools had a monopoly on music, while in larger centers they competed effectively with existing local professional ensembles. An emphatic example is the musical ensemble of St. Barbara's Church in Cracow which successfully competed with the cathedral ensemble of the same city and the ensemble of St. Peter's and St. Paul's Church, including up to 100 musicians who found work in thirty churches of the city. ${ }^{70}$ In testimony to the status of this ensemble, inventories from the years 1737,1740 , and 1757 note a repertoire rich in musical genres: Masses, offertories, vespers, litanies, Passions, motets, antiphons, arias, pastorellas, and instrumental works such as sinfonias and canzonas. ${ }^{71}$ The Jesuit boarding school of Krosno possessed an analogous collection and equally rich resources in musical instruments, listed in the inventory originating from the school. $^{72}$

69 Jerzy Kochanowicz, Podręcznik pedagogiki Stefana Czarnieckiego sJ z 1715 roku (Cracow: Wydawnictwo WAM, 2001), 95 .

70 Adolf Chybiński, "Z dziejów muzyki krakowskiej. I. Organizacja kapeli jezuickiej w pierwszej połowie XVIII w., II. Inwentarze instrumentów i muzykaliów z XVII i XVIII w." Kwartalnik muzyczny 2 (1913-14): 26-32; Delma Brough, Polish Seventeenth-Century Church Music: With Reference to the Influence of Historical, Political, and Social Conditions (Oxford: University of Oxford Press, 1981), 139-61; Jerzy Kochanowicz, "Początki jezuickiej kapeli i bursy muzycznej w Krakowie," in Jezuicka ars educandi: Prace ofiarowane księdzu profesorowi Ludwikowi Piechnikowi, ed. Ludwik Grzebień (Cracow: Wydawnictwo WAM, 1995), 266-68.

71 Jerzy Kochanowicz, Stownik geograficzny jezuickich burs muzycznych (materiaty) (Cracow: Wydawnictwo WAM, 2002), 93-113. Among the local composers, we have figuring here Grzegorz Gerwazy Gorczycki, Jacek Staromiejski, and Jacek Szczurowski, among others.

72 Roman Pelczar, "Jezuickie bursy muzyków (bursae musicorum) w diecezji przemyskiej w XVII i XVIII w." Muzyka 43, no. 1 (1998): 73-87; Roman Pelczar, Dziatalność oświatowokulturalna jezuitów polskich w diecezji przemyskiej w XVI-XVIII wieku (Przemyśl: Regionalny Ośrodek Kultury, Edukacji i Nauki w Przemyślu, 1999), 118-19. See also: Jerzy Kochanowicz, "Rękopisy muzyczne jezuickiej bursy w Grodnie w 1773 roku," in Librorum amatori: Księga pamiątkowa ofiarowana ks. Czestawowi Michalunio sJ na 5o-lecie ofiarnej pracy w 
Among the collections of Jesuit boarding school musical paraphernalia existing in the studied lands, only the collection from Święta Lipka (Heiligelinde $)^{73}$ survives in entirety. However, it contains the late repertoire from the end of the eighteenth century and after the suppression. Manuscripts of Jesuit provenance have been discovered recently in Sandomierz. ${ }^{74}$ Old prints belonging to the Jesuit college of Braniewo survived in Uppsala ${ }^{75}$ but musical manuscripts of the city's boarding school were subject to an almost complete dispersal. The organ tablature, written in the 1620 s by the Cistercian Jacob Apfell, ${ }^{76}$ who studied at the Jesuit college there, was prepared in Braniewo. Another trace of contacts between the Cistercians and Jesuits is a fascicle probably originating in Braniewo and glued into the binding of the print Speculum pietatis (1605), in possession of the Cistercians from Pelplin. ${ }^{77}$ Pieces by a monk from this monastery, Adam z Wagrowca, have been found in the organ intavolatura, completed in the Jesuit boarding school in Kražiai (Kroże). ${ }^{78}$

Bibliotece Filozoficznej Towarzystwa Jezusowego w Krakowie (Cracow: Wydawnictwo wam: 2004), 138-42.

73 Jolanta Byczkowska-Sztaba, "Die Werke von Isfrid Kayser im Repertoire der Jesuitenkapelle des Marienheiligtums zu Heiligelinde," in Oberschwäbische Klostermusik im europäischen Kontext. Alexander Sumski zum 7o. Geburtstag, ed. Ulrich Siegele (Frankfurt am Main: Peter Lang, 2004), 131-43.

74 Magdalena Walter-Mazur, "Poklasztorne rękopisy XVIII-wiecznej muzyki wokalnoinstrumentalnej i instrumentalnej w zbiorach Biblioteki Diecezjalnej w Sandomierzu: Sprawozdanie z cyklu kwerend: 16-18 I, 15-19 IV, 3-7 VI i 18-22 XI 2013 r.," Hereditas monasteriorum 3 (2013), 469-84.

75 Åke Davidsson, Catalogue critique et descriptif des imprimés de musique des XVI ${ }^{e}$ et XVII ${ }^{e}$ siècles conservés à la Bibliothèque de l'Université Royale d'Uppsala, vol. 1-3 (Uppsala: Uppsala University, 1951-2); Agnieszka Leszczyńska, "Recepcja XVI-wiecznych protestanckich druków muzycznych w Braniewskim Kolegium Jezuickim," in Muzyka wobec tradycji: Idee - Dzieto - Recepcja, ed. Szymon Paczkowski (Warsaw: Instytut Muzykologii Uniwersytetu Warszawskiego, 2004), 191-96.

76 Vilnius, Lietuvos Mokslų Akademijosvrublevskių Biblioteka F 15-284 i F 15-286. See Jan Janca, "Oliwskie tabulatury organowe (ok. 1619): Nowe źródła do historii muzyki w Gdańsku i na Warmii," in Kultura Muzyczna Pótnocnych Ziem Polski, vi. Muzyka w Gdańsku wczoraj i dziś II (Gdańsk: Akademia Muzyczna, 1992), 63-92.

77 Elżbieta Zwolińska, "Fragmenty rękopiśmiennych partesów z początku XVII w. z Archiwum Prowincji Małopolskiej Towarzystwa Jezusowego w Krakowie (PL-Kratj 1631)," in Complexus effectuum musicologiae: Studia Miroslao Perz septuagenario dedicata, ed. Tomasz Jeż (Cracow: Rabid, 2003), 53-64.

78 Jūratė Trilupaitienè, "Nieznany xvı-wieczny rękopis z Kroż," Muzyka 38, no. 1 (1993): 97-102; Adam z Wagrowca socist (†1629): Utwory z intawolatury żmudzkiej (Ms LT-Vn 105-67), ed. Irena Bieńkowska and Mirosław Perz (Warsaw: Neriton, 1999). 
The Jesuits active on the Commonwealth territory also occupied themselves with independent musical composition, despite the instructions of the German assistance superiors, forbidding Society members to compose new musical works without the provincial's permission. ${ }^{79}$ The first known Jesuit composer was Marcin Laterna, the author of a popular songbook Harfa duchowna (Cracow, 1585). ${ }^{80}$ The songs were sung by the Jesuit-founded sodalities, themselves important centers in the stimulation of musical patronage. Vernacular repertoire was also employed in the Jesuits' catechetical instruction, a practice that found favor with the Lithuanian province's authorities. ${ }^{81} \mathrm{Jan}$ Bartoszewicz published in Vilnius his Parthenomelica $(1613)^{82}$ with twenty-eight Advent songs translated from the Latin repertoire and based on the songbooks by Laterna and Stanisław Grochowski. ${ }^{83}$

The composers included Jan Brant, ${ }^{84}$ a Rome-trained prefect of music in Poznań and professor at the Academy of Vilnius. Apart from the collection Pieśni różne pospolite o różnych pobożnych potrzebach (1601), he authored a number of motets, several of which (including Iesu dulcis memoria) are preserved in the organ tablature of the Jesuit college in Riga, ${ }^{85}$ as well as a setting of Invitatorium in festo Nativitatis - the earliest Polish composition with basso seguente. A polychoral setting of the Magnificat by Melchior Fabricius (1575-1653), the Jesuit active at the court of Paweł Wołucki, bishop of Włocławek, has been copied in the Pelplin organ tablature. ${ }^{86}$

Szymon Berent (1595-1649), a prefect of a boarding school in Braniewo, also wrote the polychoral music. He wrote numerous compositions for the school, unfortunately now lost. Two of his litanies (De sanctissimo Nomine Jesu and De Beatissima Virgine) were printed in the college and were presumably performed in Rome, where Berent travelled as a chaplain of the Grand Chancellor

79 Max Wittwer, Die Musikpflege im Jesuitenorden unter besonderer Berücksichtigung der Länder deutscher Zunge (Greifswald: Grimmer Kreis-Zeitung GmbH, Grimmen in Pommern, 1934), 13.

8o Stanisław Cieślak, "Harfa duchowna - modlitewnikowy bestseller jezuity Marcina Laterny (1552-1598)," Nasza Przesztość 93 (2000): 23-48; Stownik jezuitów muzyków, 122-23.

81 Szweykowska, Wkład, 298.

82 Parthenomelica albo Pienia nabożne o Pannie Najświętszej, które poważny senat miasta wileńskiego [...] na roraciech przystojnie co rok odprawuje, ed. Wojciech Rębowski and Tadeusz Maciejewski (Warsaw: Instytut Wydawniczy PAX, 1988).

83 Stanisław Grochowski, Hymny kościelne [...] (Cracow: 1598).

84 Zygmunt M. Szweykowski, "Jan Brant (1554-1602) i jego nowo odkryta twórczość muzyczna. Z muzycznych poszukiwań w Szwecji (III)," Muzyka 27, no. 2 (1973): 43-72.

85 Uppsala, Universitetsbibliotek, Vok. mus. i hs. 88.

86 Pelplin, Diocesan Seminary Library, 308, pp. $33^{\mathrm{v}}-36^{\mathrm{r}}$. 
of Lithuania, Albrycht Stanisław Radziwiłł. Martin Kretzmer (1631-96) ${ }^{87}$ was also active in Braniewo. He was the author of the vocal-instrumental rondo concerto Sacerdotes Dei. ${ }^{88}$ In the time of the Moscow invasion of Lithuania, this Jesuit stayed in Bohemia where he acquainted himself with Kircher's treatise Musurgia universalis, as well as in Silesia where he left three solo concertos: Aeterne rerum omnium effector Deus; Laudem Te Dominum; and Memorare, o piissima Virgo ${ }^{89}$ In addition, Kretzmer wrote the now lost compositions for the beatification of Stanislaus Kostka (1670) and canonization of Francisco de Borja $(1671) \cdot{ }^{90}$

Andrzej Siewiński in turn was connected with the Jesuit boarding school in Cracow, as confirmed by the latter's musical paraphernalia inventory of 1737 . Several of his compositions have survived in the Sandomierz collections: Missa pro defunctis (1706, perhaps identical with the Requiem indicated in the Cracow inventory), Ave Regina caelorum (1713), and settings of four hymns from The Liturgy of the Hours dedicated to the Holy Blessed Virgin (1729). ${ }^{91}$

Jan Piotr Habermann (d.1762 $)^{92}$ was a violinist of the Cracow Jesuit boarding school at the same time and composed at least four works in the galant style (Iste quam laeti; Propter ardentem charitatem; O felix et beata dies; Lauda Sion) which survive in the Cistercian cloister library in Mogiła. In the 1740s, Habermann was the chapel master of the Jesuit boarding school in Lviv; however, he spent the last year of his life at the Pauline Fathers and Brothers monastery in Jasna Góra.

Jacek Szczurowski (b.1716) was another Cracow boarding school pupil, a longtime socius praefecti bursae in Kalisz, Cracow, Jarosław, Gdańsk, Kalisz, Poznan, and Wałcz. ${ }^{93}$ From the several dozen titles of his own compositions known from the Cracow inventories, eight are extant: five ensemble cantatas

87 Zygmunt M. Szweykowski, “Nieznana twórczość Marcina Krzeczmera," in Z dziejów muzyki polskiej: IX. Materiaty z IV sesji naukowej Bydgoskiego Towarzystwa Naukowego (Bydgoszcz: Bydgoskie Towarzystwo Naukowe, Filharmonia Pomorska im. Paderewskiego, 1965), 53-62.

88 Cracow, Biblioteka Jagiellońska, call n. 5272/27 and 5272.47.

89 Warsaw, Biblioteka Uniwersytecka, call n. Rм 6226, Rм 6227, and Rм 6228.

90 Jiří Sehnal, Jitřenka Pešková, Caroli de Liechtenstein-Castelcorno episcopi Olomucensis operum artis musicae collectio Cremsirii reservata (Prague: National Library, 1998), 36.

91 Barbara Wróbel, "Missa pro defunctis Andrzeja Siewińskiego na tle zbioru muzykaliów sandomierskich," Kwartalnik IM UJ (www2.muzykologia.uj.edu.pl/kwartalnik/numery/ nrg/wrobel.pdf).

92 Jan Piotr Habermann (I poł. XVIII w.), Utwory wokalno-instrumentalne, ed. Zygmunt M. Szweykowski (Cracow: Państwowe Wydawnictwo Muzyczne, 1966).

Aleksandra Wilde, “Twórczość Jacka Szczurowskiego,” Muzyka 36, no. 1 (1991): 45-98. 
(Caeli cives occurrite; Domine non sum dignus; Litania de BMV; Memento rerum conditor; Vesperae pro Sanctis), two cantata masses (Missa Emmanuelis; Missa $D$ ), as well as the Christmas concerto Dziecino Boże maintained in pastorella style. Among the lost compositions by Szczurowski, we must mention the oldest Polish symphony, dated for $175^{\circ}$.

The repertoire subject to reconstruction with the surviving musical paraphernalia of Jesuit provenance reveals a very unrepresentative character of this community's cultivation of the musical tradition in the Polish-Lithuanian Commonwealth. This tradition was expressed in an extraordinarily colorful variety of musical forms, cultivated in various types of educational and pastoral institutions under the direction of members of the Society of Jesus. Despite the Jesuit constitutional advisements limiting the active and direct engagement in the musical culture, the members in the studied region were able to create self-financing structures of musical patronage, mobilizing religiously, intellectually, culturally, and socially varied communities. Longtime work in this field brought significant advances in the scope of average musical education; in consequence it also led to meaningful changes in the social forms of functioning of music. These in turn prepared the ground for changes connected with the breakthrough of the Enlightenment, developed in Poland by the Jesuits, ${ }^{94}$ among others.

Translated by Maksymilian Kapelański and edited by the Jjs staff

94 Barbara Kryda, Szkolna i literacka dziatalność Franciszka Bohomolca: U źródet polskiego klasycyzmu XVIII w. (Wrocław: Ossolineum, 1979); Wacław Zarzycki, Biskup Adam Naruszewicz luminarz polskiego Oświecenia (Lublin: Redakcja Wydawnictw KUL, 1999); Stanisław Gawlik, Grzegorz Piramowicz - idee, stowa, czyny (Opole: Wydawnictwo Uniwersytetu Opolskiego, 2006). 